\title{
Color measurements according to three sections of wood
}

\author{
Seiji Hirata ${ }^{1 *} \mathbb{D}$, Saori Hayashi ${ }^{2}$ and Masamitsu Ohta ${ }^{3}$
}

\begin{abstract}
The purpose of this study was to measure each color of three sections of wood with instruments, and to examine whether there were differences between each color of three sections. The total number of tree species measured was 60 , with the same number of conifers and broadleaf trees. A test piece, which was a cube with one side of $34 \mathrm{~mm}$, was prepared for each tree species. End grain, edge grain, bark side and pith side of each test piece were flattened by a hand planer. Then, lightness $L^{*}$ and hue/saturation $\left(a^{*}, b^{*}\right)$ in the $L^{*} a^{*} b^{*}$ color space were measured with a spectrophotometer. The results showed that the end grain had a lower $L^{*}$ compared to the other planes. The end grain was reddish and yellowish because it had a large $a^{*}$ and small $b^{*}$. When chroma $C^{*}$ and hue angle $h$ in the $L^{*} C^{*} h$ color space were calculated from $a^{*}$ and $b^{*}$, the end grain had a small dullness with less vividness because $C^{*}$ was smaller than the other planes. $L^{*}, a^{*}, b^{*}, C^{*}$ and $h$ on the other planes excluding the end grain were almost equal for each plane. Furthermore, it was found that the plane whose lightness $L^{*}$ had the strongest correlation with the density of the test piece was the end grain. Therefore, the correlation diagrams between the density, average of annual ring width, and $L^{*}$ of the end grain of each test piece were shown.
\end{abstract}

Keywords: Three sections of wood, Glossiness, Color measurement, $L^{*} a^{*} b^{*}$ color space, $L^{*} C^{*} h$ color space, Density, Average of annual ring width

\section{Introduction}

There are many examples in measuring the color of wood with instruments for tree type, heartwood/sapwood, early wood/late wood, and knots [1-16]. However, in most of these measurement examples, it is unclear which side of the three cross-sections-end grain, edge grain, or flat grain-was measured. Even in clear cases, measurement is limited to the measurement of one plane.

For example, regarding the hardness of wood, it is stipulated in the Japanese Industrial Standard [17] that measurement be made for each of the three sections of wood. The relationship of surface hardness for three cross-sections has been clarified. In the average hardness of all tree species, the relationship of "End grain hardness $>$ Flat grain hardness $\geqq$ Edge grain hardness" [18] has been

\footnotetext{
*Correspondence: s-hirata@okayama-u.ac.jp

1 Okayama University Graduate School of Education, Tsushimanaka,

Kita-Ku, Okayama 700-8530, Japan

Full list of author information is available at the end of the article
}

clarified. We have experienced those situations, when looking at the sawed boards and square timbers, in which the color of end grain is slightly darker than the other planes. However, in past measurement examples of wood color by instruments, it is unclear whether there are any differences between the three sections.

Therefore, in this study, we measured the color of each of the three sections of test pieces of almost the same size as the test piece [17] of which the hardness of wood was measured in the Japanese Industrial Standard [17]. The number of tree species measured was 60 in total, with the same number of conifers and broadleaf trees.

\section{Materials and methods Test pieces}

To measure the color of wood in three sections, we prepared a test piece in the air-dried state of a cube with one side $34 \mathrm{~mm}$ with three clear sections as shown in Fig. 1. As shown in Table 1, a total of 60 tree species, with 30 species each of conifers and broadleaf trees, were 


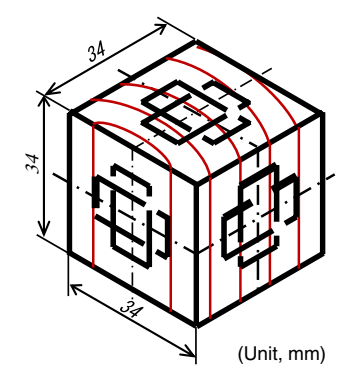

a Measured locations with gloss meter
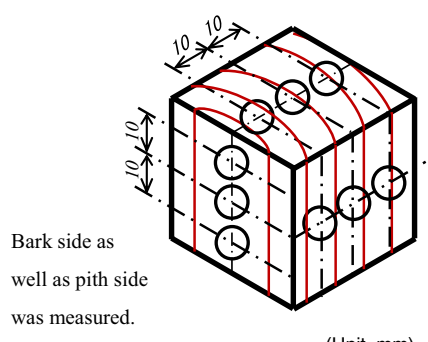

(Unit, mm)

b Measured locations with spectrophotometer
Fig. 1 Measured planes of test piece

prepared. Table 1 also shows the production area, density, and average of annual ring width-hereafter, it is abbreviated as "AARW"-of each test piece. Both production areas of conifers and broadleaf trees were halved from Japan and foreign countries. Some test pieces shown in Table 1 had clear early and late woods. There were four test pieces (Serial numbers: 3, 9, 30, and 31) whose entire surface of the bark side and the pith side were sapwood and heartwood, respectively.

Table 2 shows averages of density and AARW of conifers, broadleaf trees, or all trees in Table 1. As shown in Table 2, an unpaired $t$ test was conducted to examine the significant differences in the averages of density/AARW between conifers and broadleaf trees. It can be said that both the density and AARW of broadleaf trees are higher than those of conifers with significant differences of $5 \%$.

For each test piece, finally, using a changeable bladetype hand planer (Shimizu Seisakusho Kanna-mini J50) with a thickness of $0.04 \mathrm{~mm}$, one end grain, one edge grain, bark side and pith side of flat grain were planed. That is, each measurement plane was flattened by the same method. On the bark and pith sides of the test piece, we cut with grain.

The changeable blade was replaced each time when approximately three test pieces were planed, and the sharpness was good and constant.

\section{Glossiness and color measurement}

As shown in Fig. 1a, glossiness was measured at the center of each measurement surface with a gloss meter (NIPPON DENSHOKU PG-IIM, measurement angle $60^{\circ}$, measurement size $10.0 \times 20.0 \mathrm{~mm}$ ). Tangential direction and radial direction of the annual rings were measured on the end grain, and directions parallel and perpendicular to the fiber were measured on the edge grain and flat grain.

After glossiness of each plane was measured, three locations in the center and $10 \mathrm{~mm}$ away from it were measured with a spectrophotometer (NIPPON DENSHOKU NF333, measuring diameter $8 \mathrm{~mm}$, illumination light source), as shown in Fig. 1b. At present, the $L^{*} a^{*} b^{*}$ color space (JIS Z 8781-4 [19], ISO 11664-4 [20]) is the most popular color system [21] used in all fields to represent object colors. Therefore, in this study, we measured spectral reflectance, lightness $L^{*}$, and $a^{*}, b^{*}$ indicating hue and saturation in the $L^{*} a^{*} b^{*}$ color space.

The average of three locations on each plane measured with a spectrophotometer was used as the value for each measured plane. Then, we intended to find the average color of each of the end grain, the edge grain, the bark side, and the pith side of the target test pieces.

\section{Results and discussion Glossiness}

Figure 2 shows the averages of the glossiness of each measured plane. To support the measurement results for all trees, conifers and broadleaf trees are also shown. (Similarly, the following measurement results are shown for all trees, conifers and broadleaf trees.)

For all trees shown in Fig. 2, the value of glossiness is small on the end grain, and is almost equally large on edge grain, bark side and pith side. There is not a large difference in gloss level between the tangential direction and the radial direction on end grain, but glossiness is naturally large in the fiber direction and small in the direction perpendicular to the fiber on the other planes [22].

For conifers and broadleaf trees, it can be said that all trees are the same for both genera.

\section{Spectral reflectance}

Figure 3 shows the measured spectral reflectance as an average value. For all trees, the spectral reflectance of each plane is similar to the previously measured timber example $[3,23]$. Spectral reflectance is small on the end grain and is almost equally large on the other planes.

For conifers and broadleaf trees, it can be said that all trees are the same for both genera.

Lightness $L^{*}$ and hue/saturation $\left(a^{*}, b^{*}\right)$ in $L^{*} a^{*} b^{*}$ color space Table 3 shows the measured values of lightness $L^{*}$, and hue/saturation $\left(a^{*}, b^{*}\right)$ of measured plane of each test piece in Table 1.

\section{Lightness $L^{*}$}

Figure 4 shows the averages of the measured lightness $L^{*}$ of each plane in Table 3. For all trees, $L^{*}$ of the end grain is smaller than that of the edge grain, the bark side and pith side. $L^{*}$ of the edge grain, the bark side and the pith side are almost equal. For conifers and broadleaf trees, it can be said that all trees are the same for both genera. 
Table 1 Tree name, density, and AARW of each test piece

\begin{tabular}{|c|c|c|c|c|c|c|c|}
\hline $\begin{array}{l}\text { Serial } \\
\text { numbers }\end{array}$ & & Tree name & Scientific name & Production area & Density $\left(\mathrm{g} / \mathrm{cm}^{3}\right)$ & AARW (mm) & $\begin{array}{l}\text { Correlation } \\
\text { coefficient } \\
\text { between density } \\
\text { and AARW }\end{array}$ \\
\hline 1 & Conifers & Akamatsu & Pinus densiflora & Japan & 0.49 & 0.80 & -0.0462 \\
\hline 2 & & Kaya & Torreya nucifera & Japan & 0.46 & 5.09 & \\
\hline 3 & & Ichou* & Ginkgo biloba & Japan & 0.48 & 3.05 & \\
\hline 4 & & Sawara & $\begin{array}{l}\text { Chamaecyparis } \\
\text { pisifera }\end{array}$ & Japan & 0.34 & 3.11 & \\
\hline 5 & & Momi & Abies firma & Japan & 0.41 & 4.41 & \\
\hline 6 & & Togasawara & Pseudotsuga japonica & Japan & 0.46 & 3.27 & \\
\hline 7 & & Karamatsu & Larix kaempferi & Japan & 0.50 & 2.10 & \\
\hline 8 & & Hinoki & $\begin{array}{l}\text { Chamaecyparis } \\
\text { obtusa }\end{array}$ & Japan & 0.51 & 1.08 & \\
\hline 9 & & Sugi & Cryptomeria japonica & Japan & 0.46 & 3.32 & \\
\hline 10 & & Ezomatsu & Piceajezoensis & Japan & 0.43 & 0.80 & \\
\hline 11 & & Todomatsu & Abies sachalinensis & Japan & 0.49 & 4.18 & \\
\hline 12 & & Mizuki & Cornus controversa & Japan & 0.61 & 3.43 & \\
\hline 13 & & Yakusugi & Cryptomeria japonica & Japan & 0.40 & 0.39 & \\
\hline 14 & & Aomori hiba & Thujopsis dolabrata & Japan & 0.50 & 0.71 & \\
\hline 15 & & Himekomatsu & Pinus parviflora & Japan & 0.39 & 2.72 & \\
\hline 16 & & Noto hiba & Thujopsis dolabrata & Japan & 0.45 & 3.27 & \\
\hline 17 & & Agathis & Agathis sp. & Southeast Asia & 0.47 & 1.81 & \\
\hline 18 & & Western redceder & Thuja plicata & North America & 0.35 & 1.21 & \\
\hline 19 & & Douglas fir & Pseudotsuga menziesii & North America & 0.57 & 0.50 & \\
\hline 20 & & Taiwan cypress & $\begin{array}{l}\text { Chamaecyparis } \\
\text { taiwanensis }\end{array}$ & Taiwan & 0.54 & 1.02 & \\
\hline 21 & & Spruce & Picea sitchensis & North America & 0.51 & 0.58 & \\
\hline 22 & & Southern yellow pine & Pinus sp. & North America & 0.60 & 4.65 & \\
\hline 23 & & Western hemlock & Tsuga heterophylla & North America & 0.47 & 0.42 & \\
\hline 24 & & Merkus pine & Pinus merkusii & Laos & 0.75 & 3.33 & \\
\hline 25 & & Hard cypress & Callitris columellaris & Australia & 0.69 & 0.56 & \\
\hline 26 & & Yellow cedar & $\begin{array}{l}\text { Chamaecyparis noot- } \\
\text { katensis }\end{array}$ & North America & 0.45 & 0.95 & \\
\hline 27 & & Sequoia & Sequoia sempervirens & California & 0.44 & 4.42 & \\
\hline 28 & & Sosna & Pinus sylvestris & Europe & 0.49 & 1.32 & \\
\hline 29 & & Korean pine & Pinus koraiensis & Russia & 0.44 & 2.22 & \\
\hline 30 & & Fujian cypress & Fokienia hodginsii & Laos & 0.54 & 0.62 & \\
\hline 31 & Broadleaf trees & Udaikanmba & $\begin{array}{l}\text { Betula maximowic- } \\
\text { ziana }\end{array}$ & Japan & 0.78 & 0.75 & $-0.657^{* *}$ \\
\hline 32 & & Katsura & $\begin{array}{l}\text { Cercidiphyllum } \\
\text { japonicum }\end{array}$ & Japan & 0.46 & 3.82 & \\
\hline 33 & & Kiri & Paulownia tomentosa & Japan & 0.27 & 7.11 & \\
\hline 34 & & Sen & Kalopanax pictus & Japan & 0.65 & 1.63 & \\
\hline 35 & & Buna & Fagus crenata & Japan & 0.74 & 2.42 & \\
\hline 36 & & Doronoki & Populus maximowiczii & Japan & 0.42 & 9.66 & \\
\hline 37 & & Shirakaba & Betula platyphylla & Japan & 0.56 & 1.73 & \\
\hline 38 & & Shirakashi & Quercus myrsinaefolia & Japan & 0.92 & 2.98 & \\
\hline 39 & & Yachidamo & Fraxinus mandshurica & Japan & 0.64 & 1.70 & \\
\hline 40 & & Kuri & Castanea crenata & Japan & 0.60 & 2.29 & \\
\hline 41 & & Hoonoki & Magnolia obovate & Japan & 0.51 & 1.89 & \\
\hline 42 & & Keyaki & Zelkova serrata & Japan & 0.55 & 1.64 & \\
\hline 43 & & Onigurumi & Juglans mandshurica & Japan & 0.44 & 1.72 & \\
\hline
\end{tabular}


Table 1 (continued)

\begin{tabular}{|c|c|c|c|c|c|c|}
\hline $\begin{array}{l}\text { Serial } \\
\text { numbers }\end{array}$ & Tree name & Scientific name & Production area & Density $\left(\mathrm{g} / \mathrm{cm}^{3}\right)$ & AARW (mm) & $\begin{array}{l}\text { Correlation } \\
\text { coefficient } \\
\text { between density } \\
\text { and AARW }\end{array}$ \\
\hline 44 & Kusunoki & $\begin{array}{l}\text { Cinnamomum cam- } \\
\text { phora }\end{array}$ & Japan & 0.52 & 4.30 & \\
\hline 45 & Popura & Populus nigra & Japan & 0.41 & 4.68 & \\
\hline 46 & Balsa & Ochroma lagopus & Latin America & 0.14 & 11.68 & \\
\hline 47 & White ash & Fraxinus americana & North America & 0.77 & 1.84 & \\
\hline 48 & Teak & Tectona grandis & Myanmar & 0.72 & 1.35 & \\
\hline 49 & Aspen & Populus tremuloides & North America & 0.46 & 4.51 & \\
\hline 50 & Alder & Alnus rubra & North America & 0.52 & 4.68 & \\
\hline 51 & White oak & Quercus alba & North America & 0.73 & 1.30 & \\
\hline 52 & Jelutong & Dyera costulata & Southeast Asia & 0.44 & 1.65 & \\
\hline 53 & Hard maple & Acer saccharum & North America & 0.77 & 3.41 & \\
\hline 54 & Assamela & Pericopsis elata & Africa & 0.71 & 3.83 & \\
\hline 55 & Soft maple & Acer rubrum & China & 0.48 & 2.33 & \\
\hline 56 & Hackberry & Celtis Occidentalis & North America & 0.64 & 2.40 & \\
\hline 57 & Surian & Toona sureni & Southeast Asia & 0.35 & 5.24 & \\
\hline 58 & Coffee tree & Coffea arabica & North America & 0.69 & 3.07 & \\
\hline 59 & Mersawa & Anisoptera sp. & Southeast Asia & 0.60 & 2.67 & \\
\hline 60 & Black cherry & Prunus serotina & North America & 0.75 & 3.48 & \\
\hline \multicolumn{4}{|c|}{ Correlation coefficient between density and AARW in all trees } & $-0.376^{* *}$ & & \\
\hline
\end{tabular}

AARW average of annual ring width

A comment on Tree name * "Ichou" is not a conifer, but is listed here for convenience

Significance test results of correlation coefficient ${ }^{* *} p<0.01$

Table 2 Average values of density and AARW in Table 1

\begin{tabular}{|c|c|c|c|c|}
\hline & \multicolumn{2}{|c|}{ Density $\left(\mathrm{g} / \mathrm{cm}^{3}\right)$} & \multicolumn{2}{|c|}{ AARW $(\mathrm{mm})$} \\
\hline & Average & S.D. & Average & S.D. \\
\hline Conifers & $*\lceil 0.490$ & 0.088 & $* \Gamma 2.178$ & 1.479 \\
\hline $\begin{array}{c}\text { Broadleaf } \\
\text { trees }\end{array}$ & L 0.575 & 0.168 & L 3.391 & 2.410 \\
\hline All trees & 0.532 & 0.141 & 2.784 & 2.088 \\
\hline
\end{tabular}

Unpaired $t$ test results of differences between conifers and broadleaf tres

* $p<0.05$

Table 4 shows the results of paired mean difference tests between each measured $L^{*}$ of each plane in Fig. 4. From Table 4, there are significant differences of $1 \%$ between the $L^{*}$ of the end grain and that of the other planes for all trees, both conifers and broadleaf trees.
The reason for the low spectral reflectance and the low lightness $L^{*}$ of end grain in Figs. 3 and 4 seems to be related to the low glossiness of the end grain in Fig. 2. 


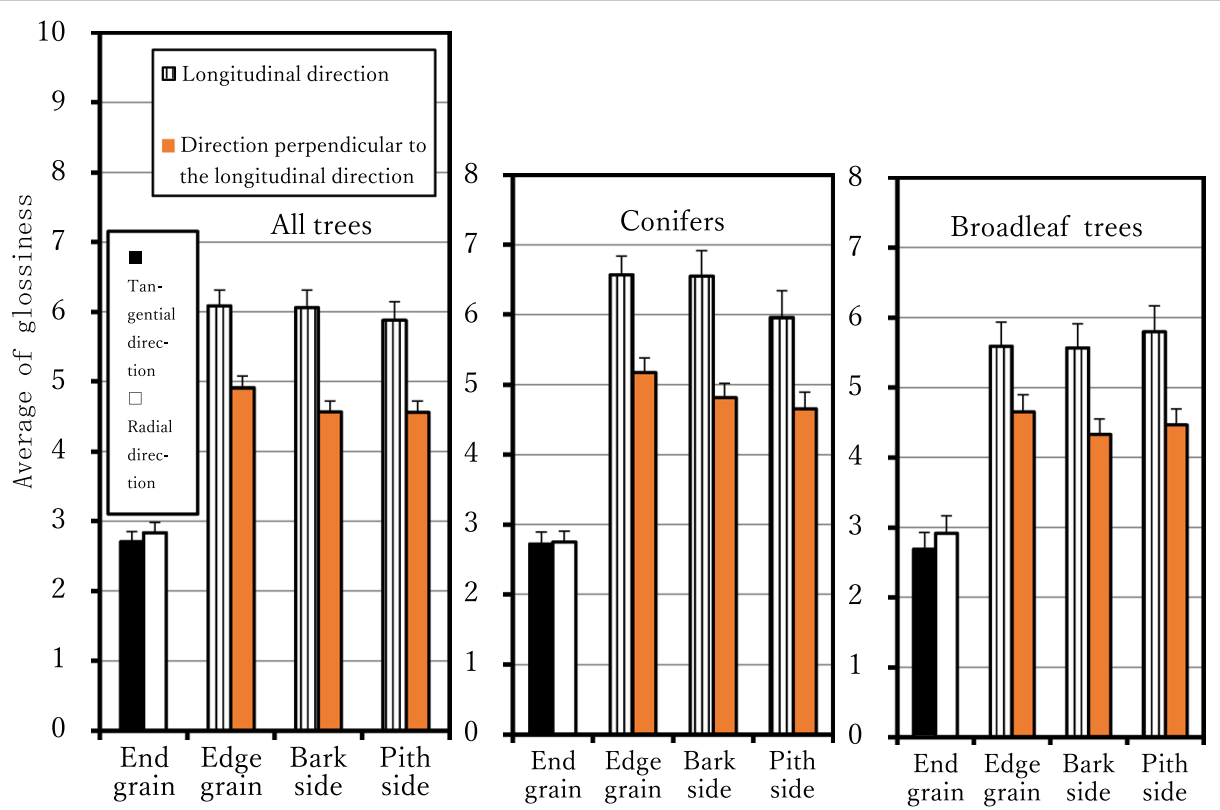

Fig. 2 Glossiness of measured planes in test pieces. Only standard errors for the plus side are shown at the end of each bar

\section{Hue/saturation $\left(a^{*}, b^{*}\right)$}

Figure 5 shows the relationship between $a^{*}$ and $b^{*}$ representing the hue and saturation of each measured plane in Table 3. For all trees, end grain has larger $a^{*}$ and smaller $b^{*}$ than those of other planes. This means that the end grain is more reddish and less yellowish than the other planes. This is true for both conifers and broadleaf trees.

For each of $a^{*}$ and $b^{*}$ shown in Fig. 5, the paired $t$ tests of average differences between each plane were tested, and the results are shown in Table 5. For all trees, significant differences of $1 \%$ level are recognized between the end grain and each of the other planes for both $a^{*}$ and $b^{*}$.

On $a^{*}$ for conifers, significant differences are recognized between the end grain and both edge grain, bark side. But there is no significant difference between the end grain and the pith side. On $b^{*}$ for conifers, significant differences of $1 \%$ level are recognized between the end grain and each of the other planes.
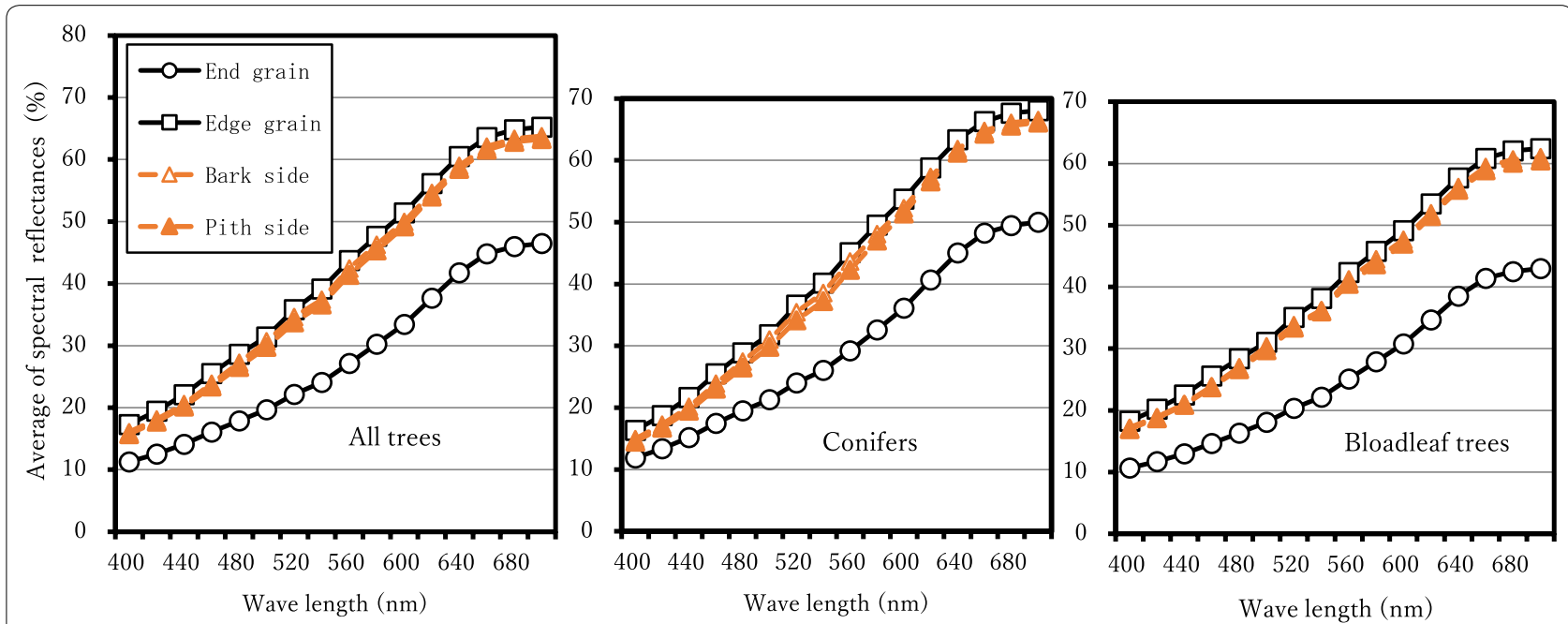

Fig. 3 Spectral references of measured planes in test pieces 
Table 3 Measured lightness $L^{*}$ and hue/saturation $\left(a^{*}, b^{*}\right)$ in $L^{*} a^{*} b^{*}$ color space

\begin{tabular}{|c|c|c|c|c|c|c|c|c|c|c|c|c|c|}
\hline \multirow{2}{*}{$\begin{array}{l}\text { Serial } \\
\text { numbers }\end{array}$} & & \multicolumn{3}{|c|}{ End grain } & \multicolumn{3}{|c|}{ Edge grain } & \multicolumn{3}{|c|}{ Bark side } & \multicolumn{3}{|c|}{ Pith side } \\
\hline & & $L^{*}$ & $a^{*}$ & $b^{*}$ & $L^{*}$ & $a^{*}$ & $b^{*}$ & $L^{*}$ & $a^{*}$ & $b^{*}$ & $L^{*}$ & $a^{*}$ & $b^{*}$ \\
\hline 1 & Conifers & 56.70 & 10.21 & 23.39 & 68.17 & 9.33 & 31.44 & 67.06 & 10.20 & 35.60 & 65.07 & 12.02 & 32.12 \\
\hline 2 & & 76.95 & 5.50 & 30.22 & 80.62 & 3.96 & 34.90 & 80.12 & 4.36 & 34.90 & 79.49 & 4.65 & 35.31 \\
\hline 3 & & 64.76 & 6.89 & 23.98 & 71.54 & 6.85 & 32.12 & 75.32 & 3.27 & 28.18 & 67.95 & 7.84 & 32.65 \\
\hline 4 & & 64.26 & 8.06 & 23.91 & 74.08 & 6.97 & 29.67 & 73.12 & 7.35 & 30.78 & 75.30 & 6.88 & 27.92 \\
\hline 5 & & 71.30 & 6.62 & 22.84 & 78.77 & 3.92 & 23.36 & 72.17 & 6.60 & 25.02 & 74.28 & 5.71 & 28.47 \\
\hline 6 & & 56.75 & 13.33 & 26.61 & 71.40 & 9.07 & 26.28 & 64.43 & 13.22 & 28.67 & 69.37 & 9.79 & 28.84 \\
\hline 7 & & 66.05 & 7.30 & 20.86 & 73.68 & 8.12 & 28.49 & 69.41 & 9.69 & 30.88 & 70.82 & 10.08 & 28.84 \\
\hline 8 & & 66.32 & 5.55 & 19.90 & 77.68 & 3.99 & 25.36 & 78.63 & 2.95 & 25.06 & 77.46 & 3.67 & 26.96 \\
\hline 9 & & 58.70 & 9.46 & 25.52 & 72.63 & 6.13 & 26.11 & 74.49 & 3.48 & 25.14 & 60.41 & 14.47 & 23.78 \\
\hline 10 & & 69.90 & 7.81 & 27.24 & 81.21 & 3.06 & 26.48 & 83.75 & 2.07 & 26.99 & 76.44 & 5.38 & 28.54 \\
\hline 11 & & 65.86 & 7.69 & 25.12 & 78.68 & 2.98 & 26.02 & 77.05 & 3.27 & 28.80 & 75.80 & 3.36 & 28.40 \\
\hline 12 & & 71.10 & 4.33 & 23.83 & 82.11 & 1.64 & 22.32 & 77.25 & 2.45 & 22.25 & 76.33 & 3.20 & 24.08 \\
\hline 13 & & 49.98 & 8.89 & 17.40 & 60.96 & 11.27 & 25.83 & 57.98 & 13.19 & 27.88 & 62.09 & 10.48 & 26.17 \\
\hline 14 & & 57.14 & 4.46 & 18.65 & 69.17 & 5.32 & 32.58 & 71.07 & 4.75 & 31.04 & 72.16 & 5.53 & 29.17 \\
\hline 15 & & 73.60 & 6.12 & 23.85 & 80.73 & 4.20 & 30.26 & 78.29 & 4.12 & 32.65 & 81.72 & 2.39 & 31.00 \\
\hline 16 & & 67.09 & 5.52 & 21.40 & 81.09 & 2.11 & 26.13 & 78.62 & 1.77 & 29.76 & 75.04 & 5.42 & 27.79 \\
\hline 17 & & 49.56 & 6.12 & 17.66 & 59.42 & 8.85 & 28.61 & 63.96 & 8.81 & 28.35 & 63.58 & 8.23 & 28.01 \\
\hline 18 & & 48.45 & 5.42 & 19.18 & 50.77 & 7.04 & 22.48 & 45.71 & 7.53 & 21.31 & 44.78 & 7.57 & 21.09 \\
\hline 19 & & 55.51 & 11.72 & 23.39 & 69.71 & 10.99 & 29.56 & 72.77 & 8.98 & 28.42 & 72.26 & 8.97 & 30.95 \\
\hline 20 & & 57.42 & 9.40 & 23.23 & 72.68 & 8.48 & 34.17 & 70.14 & 7.95 & 34.69 & 70.15 & 9.43 & 34.64 \\
\hline 21 & & 50.14 & 12.90 & 22.48 & 68.73 & 9.09 & 30.16 & 69.54 & 8.87 & 28.59 & 69.06 & 8.23 & 26.43 \\
\hline 22 & & 57.50 & 10.82 & 24.72 & 75.18 & 4.16 & 32.20 & 78.78 & 3.05 & 31.35 & 72.45 & 4.95 & 31.67 \\
\hline 23 & & 63.28 & 6.58 & 20.38 & 71.70 & 6.85 & 25.63 & 73.83 & 6.06 & 27.54 & 70.86 & 7.15 & 28.81 \\
\hline 24 & & 48.37 & 8.09 & 17.78 & 60.12 & 13.28 & 27.76 & 55.41 & 12.00 & 23.80 & 65.31 & 11.38 & 28.15 \\
\hline 25 & & 47.02 & 9.01 & 18.43 & 56.97 & 12.00 & 26.72 & 60.45 & 10.80 & 28.82 & 54.20 & 10.61 & 27.11 \\
\hline 26 & & 67.26 & 9.78 & 30.44 & 78.62 & 5.18 & 32.46 & 76.63 & 5.46 & 33.51 & 77.62 & 5.84 & 34.06 \\
\hline 27 & & 53.43 & 12.72 & 18.54 & 67.14 & 12.38 & 22.09 & 65.65 & 12.74 & 26.41 & 65.28 & 12.73 & 24.63 \\
\hline 28 & & 65.22 & 10.41 & 25.35 & 79.70 & 3.85 & 24.63 & 78.90 & 3.62 & 27.82 & 78.28 & 3.98 & 29.43 \\
\hline 29 & & 61.42 & 11.68 & 24.18 & 77.11 & 6.56 & 25.97 & 71.77 & 8.20 & 30.24 & 77.65 & 6.50 & 27.36 \\
\hline 30 & & 50.05 & 6.13 & 14.71 & 66.66 & 7.62 & 27.96 & 64.85 & 6.70 & 28.87 & 64.59 & 7.20 & 27.96 \\
\hline 31 & Broadleaf trees & 47.77 & 11.88 & 22.44 & 62.02 & 9.37 & 28.33 & 71.47 & 5.38 & 26.23 & 66.71 & 9.80 & 27.72 \\
\hline 32 & & 55.13 & 9.24 & 23.54 & 61.91 & 9.29 & 25.47 & 59.11 & 11.24 & 26.69 & 62.76 & 8.73 & 25.39 \\
\hline 33 & & 64.24 & 3.90 & 17.12 & 74.62 & 2.30 & 20.71 & 70.56 & 3.88 & 19.80 & 74.09 & 3.05 & 20.50 \\
\hline 34 & & 49.16 & 8.27 & 19.48 & 68.05 & 5.35 & 20.51 & 65.97 & 6.55 & 22.84 & 68.80 & 5.46 & 21.20 \\
\hline 35 & & 58.42 & 11.90 & 26.07 & 70.99 & 7.98 & 25.55 & 68.14 & 9.42 & 27.39 & 68.19 & 9.50 & 27.35 \\
\hline 36 & & 78.39 & 3.72 & 20.49 & 89.72 & -1.43 & 19.87 & 83.65 & -0.52 & 23.35 & 86.67 & -1.32 & 22.04 \\
\hline 37 & & 61.08 & 7.39 & 18.88 & 76.99 & 3.59 & 22.58 & 81.79 & 2.34 & 22.89 & 78.93 & 3.89 & 21.73 \\
\hline 38 & & 54.75 & 6.52 & 21.15 & 63.19 & 5.57 & 25.11 & 67.65 & 4.86 & 24.46 & 62.13 & 5.65 & 26.24 \\
\hline 39 & & 49.97 & 9.72 & 22.27 & 67.47 & 7.22 & 25.02 & 62.69 & 8.48 & 25.32 & 65.83 & 7.33 & 26.14 \\
\hline 40 & & 61.72 & 4.94 & 20.59 & 74.67 & 3.24 & 23.43 & 74.58 & 2.94 & 23.92 & 75.24 & 2.60 & 23.61 \\
\hline 41 & & 42.63 & 2.32 & 14.79 & 56.87 & 3.26 & 21.48 & 53.93 & 4.07 & 20.35 & 49.35 & 3.45 & 21.36 \\
\hline 42 & & 50.41 & 10.13 & 26.19 & 69.41 & 6.37 & 27.42 & 63.14 & 7.60 & 28.04 & 69.03 & 6.68 & 26.40 \\
\hline 43 & & 49.67 & 7.37 & 16.41 & 66.42 & 7.59 & 20.91 & 61.83 & 8.46 & 24.95 & 64.36 & 7.23 & 25.02 \\
\hline 44 & & 59.41 & 7.81 & 23.23 & 71.32 & 6.74 & 28.24 & 69.03 & 5.45 & 25.40 & 71.60 & 5.17 & 27.56 \\
\hline 45 & & 67.08 & 5.72 & 20.85 & 76.12 & 3.69 & 21.88 & 74.52 & 4.11 & 24.31 & 78.31 & 2.43 & 24.00 \\
\hline 46 & & 73.45 & 3.38 & 24.09 & 83.49 & 1.37 & 18.18 & 83.05 & 0.33 & 17.55 & 81.46 & 1.06 & 18.43 \\
\hline 47 & & 56.39 & 8.39 & 24.08 & 74.74 & 4.31 & 24.63 & 78.92 & 2.59 & 28.49 & 72.09 & 4.67 & 25.12 \\
\hline 48 & & 39.41 & 5.47 & 16.48 & 47.10 & 6.96 & 22.47 & 48.97 & 6.49 & 24.06 & 45.67 & 7.21 & 22.71 \\
\hline
\end{tabular}


Table 3 (continued)

\begin{tabular}{|c|c|c|c|c|c|c|c|c|c|c|c|c|}
\hline \multirow{2}{*}{$\begin{array}{l}\text { Serial } \\
\text { numbers }\end{array}$} & \multicolumn{3}{|c|}{ End grain } & \multicolumn{3}{|c|}{ Edge grain } & \multicolumn{3}{|c|}{ Bark side } & \multicolumn{3}{|c|}{ Pith side } \\
\hline & $L^{*}$ & $a^{*}$ & $b^{*}$ & $L^{*}$ & $a^{*}$ & $b^{*}$ & $L^{*}$ & $a^{*}$ & $b^{*}$ & $L^{*}$ & $a^{*}$ & $b^{*}$ \\
\hline 49 & 72.34 & 7.55 & 31.02 & 84.24 & -0.82 & 21.37 & 81.83 & 0.50 & 28.01 & 87.24 & -1.21 & 23.91 \\
\hline 50 & 55.77 & 8.44 & 20.28 & 65.27 & 8.12 & 26.39 & 67.63 & 8.12 & 24.57 & 65.74 & 8.10 & 23.87 \\
\hline 51 & 50.67 & 7.12 & 20.21 & 62.89 & 6.50 & 26.01 & 65.40 & 6.34 & 24.44 & 61.79 & 6.92 & 25.26 \\
\hline 52 & 62.25 & 9.40 & 26.80 & 70.54 & 7.28 & 31.45 & 72.09 & 5.37 & 30.71 & 72.59 & 5.25 & 32.20 \\
\hline 53 & 59.67 & 11.00 & 26.09 & 76.34 & 4.92 & 23.30 & 77.72 & 4.99 & 25.60 & 76.62 & 5.57 & 24.64 \\
\hline 54 & 42.45 & 6.37 & 16.21 & 58.77 & 8.99 & 27.91 & 53.85 & 9.18 & 26.22 & 53.22 & 8.30 & 23.28 \\
\hline 55 & 55.66 & 10.11 & 19.92 & 73.51 & 8.37 & 22.48 & 74.72 & 5.69 & 17.38 & 70.46 & 9.32 & 25.53 \\
\hline 56 & 62.50 & 8.88 & 27.27 & 79.75 & 3.50 & 25.10 & 75.27 & 3.47 & 27.73 & 73.70 & 3.95 & 26.37 \\
\hline 57 & 40.30 & 12.56 & 20.94 & 52.97 & 15.06 & 25.15 & 49.40 & 15.11 & 27.65 & 47.54 & 15.38 & 26.53 \\
\hline 58 & 49.15 & 13.76 & 22.90 & 77.89 & 6.53 & 23.93 & 74.32 & 8.40 & 27.08 & 69.35 & 8.36 & 29.68 \\
\hline 59 & 63.22 & 7.23 & 25.81 & 72.34 & 6.52 & 31.37 & 72.20 & 6.53 & 31.63 & 65.64 & 8.21 & 28.19 \\
\hline 60 & 47.62 & 11.85 & 19.46 & 60.86 & 13.86 & 28.53 & 56.17 & 14.81 & 29.72 & 59.55 & 14.31 & 27.09 \\
\hline
\end{tabular}

The serial numbers are the same as in Table 1
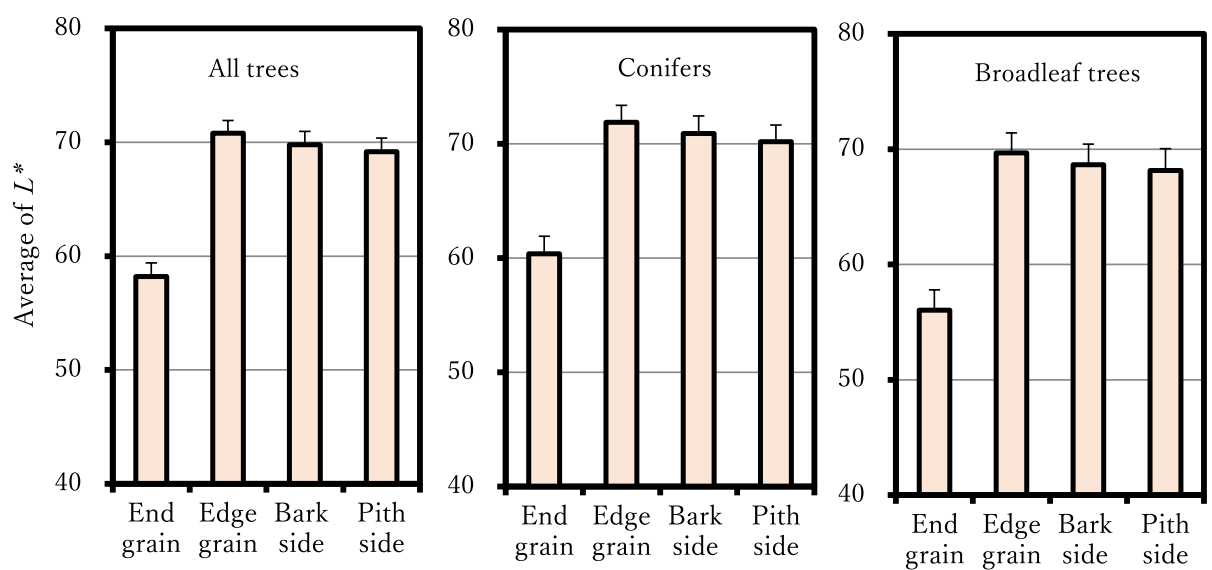

Fig. 4 Lightness $L^{*}$ of measured planes of test pieces. Only standard errors for the plus side are shown at the end of each bar

For broadleaf trees, there are significant differences of $1 \%$ between the end grain and each of the other planes for both $a^{*}$ and $b^{*}$.

\section{Calculation of chroma $C^{*}$ and hue angle $h$ in $L^{*} C^{*} h$ color space}

From the measured values $a^{*}$ and $b^{*}$ in $L^{*} a^{*} b^{*}$ color space of each test piece shown in Table 3, the chroma $C^{*}$ and the hue angle $h$ in $L^{*} C^{*} h$ color space were calculated by the following two equations $[7,16,21]$.

$$
C^{*}=\sqrt{\left(a^{*}\right)^{2}+\left(b^{*}\right)^{2}}
$$

$$
h=\tan ^{-1}\left(\frac{a^{*}}{b^{*}}\right)\left(^{\circ}\right)
$$

Figure 6 shows the averages of the calculated $C^{*}$ and $h$. Table 6 shows the results of the paired $t$ test of the differences between the average values of each measurement plane for each $C^{*}$ and $h$ shown in Fig. 6 .

According to Fig. 6 and Table 6, for all trees, both $C^{*}$ and $h$ are the smallest on the end grain, and are almost the same values on the other planes. For both $C^{*}$ and $h$, there are significant differences between the end grain and each of the other planes. Therefore, it can be said that the end grain is a dull color with less vividness and a strong reddish color compared to other planes.

Focusing on both conifers and broadleaf trees, significant differences are recognized in $C^{*}$ and $h$ between 
Table 4 Paired $t$ test results of differences between each measuring plane average on $L^{*}$ in Fig. 4

\begin{tabular}{llll}
\hline & Edge grain & Bark side & Pith side \\
\hline All trees & & $* *$ & $* *$ \\
End grain & $* *$ & $*$ & $* *$ \\
Edge grain & - & - & n.s. \\
Bark side & - & & \\
Conifers & & $* *$ & $* *$ \\
End grain & $* *$ & n.s. & $*$ \\
Edge grain & - & - & n.s. \\
Bark side & - & & $* *$ \\
Broadleaf trees & & $* *$ & $*$ \\
End grain & $* *$ & n.s. & n.s. \\
Edge grain & - & - & \\
Bark side & - & &
\end{tabular}

n.s. not significant

Significance level ${ }^{*} p<0.05,{ }^{*} p<0.01$

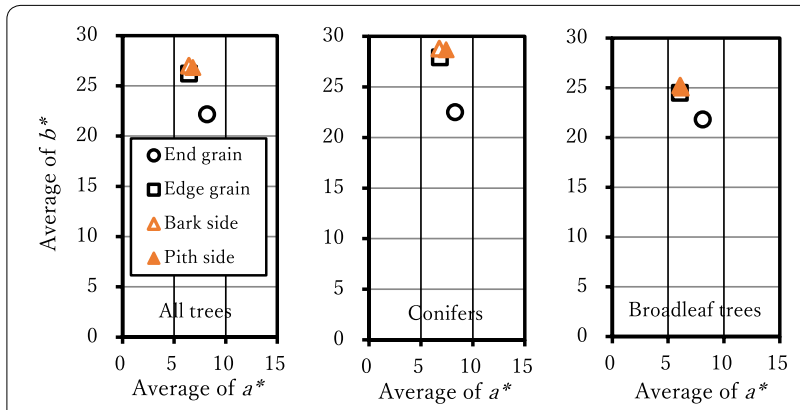

Fig. 5 Correlation diagrams between $a^{*}$ and $b^{*}$

the end grain and the other planes. Then, in $L^{*} C^{*} h$ color space, all that was mentioned for all trees can be said for both conifers and broadleaf trees.

\section{Relationships between density of test piece and lightness $L^{*}$, hue/saturation $\left(a^{*}, b^{*}\right)$, chroma $C^{*}$, and hue angle $h$ of each plane}

One text on wood colors states that "the higher the density, the lower the lightness, and the lower the density, the higher the lightness" [8]. This text does not describe which of the three planes it is referring to. In this study, we investigated the relationship between density and lightness $L^{*}$ of each measured plane of each test piece. In addition, the relationships between density and hue/ saturation $\left(a^{*}, b^{*}\right)$, chroma $C^{*}$, and hue angle $h$ were also examined.
Table 5 Paired $t$ test results of differences between each measuring plane on $a^{*}$ and $b^{*}$ in Fig. 5

\begin{tabular}{|c|c|c|c|}
\hline & Edge grain & Bark side & Pith side \\
\hline \multicolumn{4}{|l|}{ All trees } \\
\hline \multicolumn{4}{|l|}{ On $a^{*}$} \\
\hline End grain & $* *$ & $* *$ & $* *$ \\
\hline Edge grain & - & n.s. & n.s. \\
\hline Bark side & - & - & n.s. \\
\hline \multicolumn{4}{|l|}{ On $b^{*}$} \\
\hline End grain & $* *$ & $* *$ & $* *$ \\
\hline Edge grain & - & $*$ & * \\
\hline Bark side & - & - & n.s. \\
\hline \multicolumn{4}{|l|}{ Conifers } \\
\hline \multicolumn{4}{|l|}{ On $a^{*}$} \\
\hline End grain & * & $*$ & n.s. \\
\hline Edge grain & - & n.s. & n.s. \\
\hline Bark side & - & - & n.s. \\
\hline \multicolumn{4}{|l|}{ On $b^{*}$} \\
\hline End grain & $* *$ & $* *$ & $* *$ \\
\hline Edge grain & - & $*$ & n.s. \\
\hline Bark side & - & - & n.s. \\
\hline \multicolumn{4}{|l|}{ Broadleaf trees } \\
\hline \multicolumn{4}{|l|}{ On $a^{*}$} \\
\hline End grain & $* *$ & $* *$ & $* *$ \\
\hline Edge grain & - & n.s. & n.s. \\
\hline Bark side & - & - & n.s. \\
\hline \multicolumn{4}{|l|}{ On $b^{*}$} \\
\hline End grain & $* *$ & $* *$ & $* *$ \\
\hline Edge grain & - & $*$ & n.s. \\
\hline Bark side & - & - & n.s. \\
\hline
\end{tabular}

n.s. not significant

Significance level ${ }^{*} p<0.05,{ }^{* *} p<0.01$

Figure 7 shows the correlation coefficients between test piece density and $L^{*}, a^{*}, b^{*}, C^{*}$, and $h$ of each measurement plane. For all trees, the strongest correlation with density is recognized with $L^{*}$ of the end grain, indicating a significance level of $1 \%$.

For broadleaf trees, there was the strongest correlation between density and $L^{*}$ of the end grain with a significance level of $5 \%$. For conifers, there was also the strongest but not significant.

From Fig. 7, the density seems to have the strongest correlation with the lightness $L^{*}$, but it is the lightness $L^{*}$ of the end grain.

Since the relationships between density and $L^{*}$ of the end grain were found to be strong, Fig. 8 shows the 

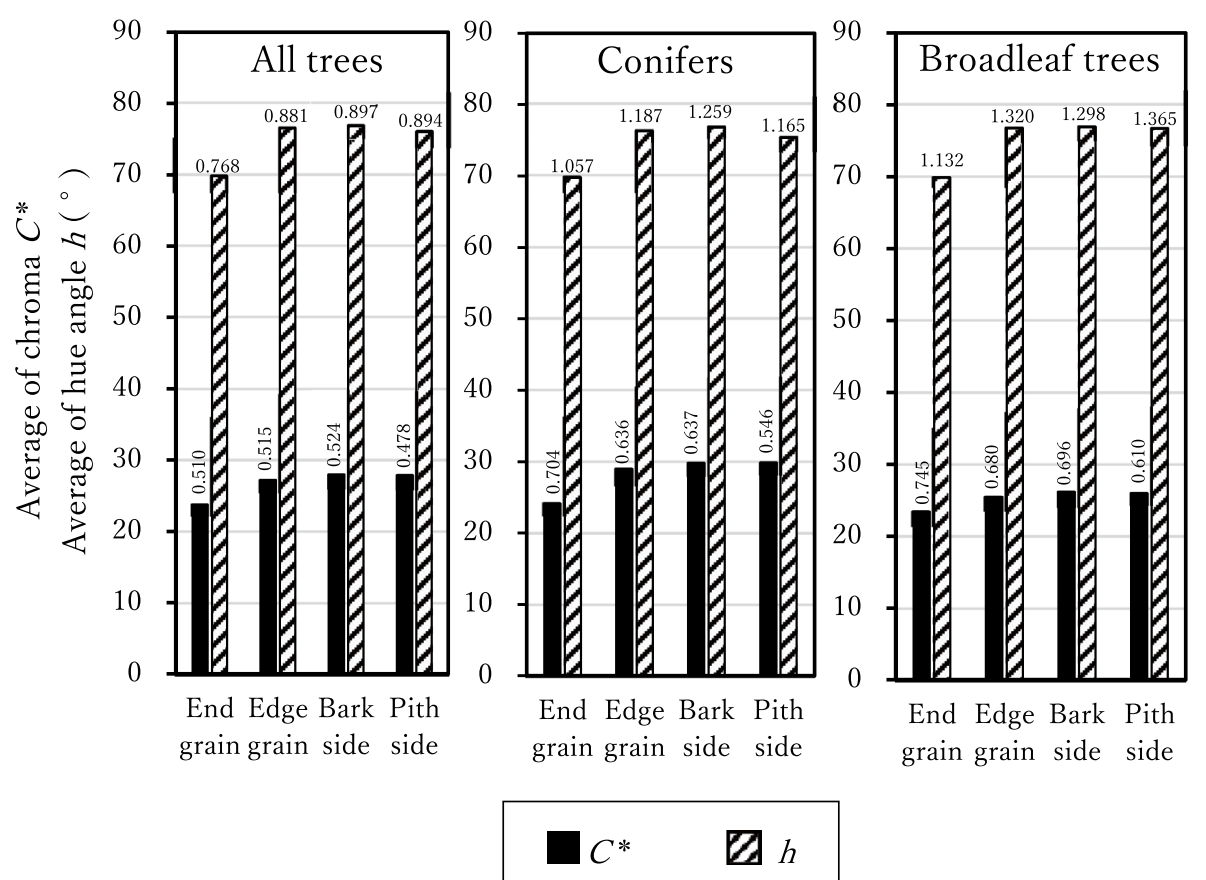

Fig. 6 Calculated Chroma $C^{*}$ and Hue angle $h$ in $L^{*} C^{*} h$ color space. Standard error values are shown near the tip of each bar

correlation diagrams between the density of each test piece and $L^{*}$ of the end grain. Figure 8 also shows the regression equations that estimate the $L^{*}$ of the end grain by density for all trees and broadleaf trees for which the correlation coefficients between the density and the $L^{*}$ of the end grain are significant in Fig. 7.

\section{Relationships between AARW of each test piece and lightness $L^{*}$, hue/saturation $\left(a^{*}, b^{*}\right)$, chroma $C^{*}$, and hue angle $h$ of each plane}

In Figs. 7 and 8, there was no significant correlation between density and lightness $L^{*}$ of the end grain for conifers. Therefore, we investigated into the relationship between AARW instead of density and $L^{*}$ of each measured plane of each test piece. In addition, the relationships between AARW and hue/saturation $\left(a^{*}, b^{*}\right)$, chroma $C^{*}$, and hue angle $h$ were also examined.

Figure 9 shows the correlations between test pieces AARW and $L^{*}, a^{*}, b^{*}, C^{*}$, and $h$ of each measured plane. For all trees, conifers and broadleaf trees, the strongest correlations with AARW are recognized with $L^{*}$ of the end grain, indicating significance levels. Then, Fig. 10 shows the correlation diagrams between the AARW and $L^{*}$ of the end grain of each test piece. Figure 10 also shows the regression equations that estimate the $L^{*}$ of the end grain by AARW.

From Figs. 7, 8, 9 and 10, $L^{*}$ of end grain seems to be affected not only by density but also by AARW.

In Figs. 8 and 10, there were some test pieces that deviated considerably from the equations for estimating $L^{*}$ by density or AARW. We could find recent papers [2426] of the differences in reflectance depending on the fiber direction of wood. So the elucidation of the factor of lightness $L^{*}$ value of wood surface will be for further study.

\section{Conclusion}

To examine whether there are differences in color depending on the three sections of wood, 60 test pieces of a cube with one side of $34 \mathrm{~mm}$ were prepared for 30 conifers and 30 broadleaf trees. After the end grain, edge gain, bark side and pith side of each test piece were flattened by a same method of hand plane; lightness $L^{*}$ and hue/saturation $\left(a^{*}, b^{*}\right)$ in the $L^{*} a^{*} b^{*}$ color space were measured with a spectrophotometer. Each plane was compared to each other.

When the target of consideration was all trees used in this experiment, the following results were obtained. 
Table 6 Paired $t$ test results of differences between each measuring plane on $C^{*}, h$ in Fig. 6

\begin{tabular}{|c|c|c|c|}
\hline & Edge grain & Bark side & Pith side \\
\hline \multicolumn{4}{|l|}{ All trees } \\
\hline \multicolumn{4}{|l|}{ On $C^{*}$} \\
\hline End grain & $* *$ & $* *$ & $* *$ \\
\hline Edge grain & - & $*$ & $* *$ \\
\hline Bark side & - & - & n.s. \\
\hline \multicolumn{4}{|l|}{ Onh } \\
\hline End grain & $* *$ & $* *$ & $* *$ \\
\hline Edge grain & - & n.s. & n.s. \\
\hline Bark side & - & - & n.s. \\
\hline \multicolumn{4}{|l|}{ Conifers } \\
\hline \multicolumn{4}{|l|}{ On $C^{*}$} \\
\hline End grain & $* *$ & $* *$ & $* *$ \\
\hline Edge grain & - & n.s. & $*$ \\
\hline Bark side & - & - & n.s. \\
\hline \multicolumn{4}{|l|}{ On $h$} \\
\hline End grain & $* *$ & $* *$ & $* *$ \\
\hline Edge grain & - & n.s. & n.s. \\
\hline Bark side & - & - & n.s. \\
\hline \multicolumn{4}{|l|}{ Broadleaf trees } \\
\hline \multicolumn{4}{|l|}{ On $C^{*}$} \\
\hline End grain & * & $* *$ & $* *$ \\
\hline Edge grain & - & n.s. & n.s. \\
\hline Bark side & - & - & n.s. \\
\hline \multicolumn{4}{|l|}{ On $h$} \\
\hline End grain & $* *$ & $* *$ & $* *$ \\
\hline Edge grain & - & n.s. & n.s. \\
\hline Bark side & - & - & n.s. \\
\hline
\end{tabular}

n.s. not significant

Significance level ${ }^{*} p<0.05,{ }^{* *} p<0.01$
(1) The end grain had a lower lightness $L^{*}$ than those of the other planes. In addition, the end grain was reddish and yellowish because it had a larger $a^{*}$ and a smaller $b^{*}$ compared to the other planes.

(2) From $a^{*}$ and $b^{*}$ measured, chroma $C^{*}$ and hue angle $h$ in the $L^{*} C^{*} h$ color space were calculated. As a result, it could be seen that the end grain was dull with less vividness because $C^{*}$ was smaller than the other planes. In addition, since $h$ on the end grain was small, it was confirmed that redness was strong on it, as was also found in $L^{*} a^{*} b^{*}$ color space.

(3) Lightness $L^{*}$, hue/saturation $\left(a^{*}, b^{*}\right)$, chroma $C^{*}$, and hue angle $h$ on the other planes excluding the end grain were almost equal for each plane.

(4) The plane whose lightness $L^{*}$ had the strongest correlation with the density of the test piece was the end grain.

(5) The correlation diagrams between the density, average of annual ring width, and $L^{*}$ of the end grain of each test piece were shown.

And, when the targets of consideration were focused on conifers and broadleaf trees, most of the above be similarly applied for both tree genera.

From the above, it has been clarified that the color of the end grain has characteristics contrasting with other planes. To elucidate the cause, it may be necessary to examine the differences in color depending on the angle at which the cell is cut, but this is the future task.

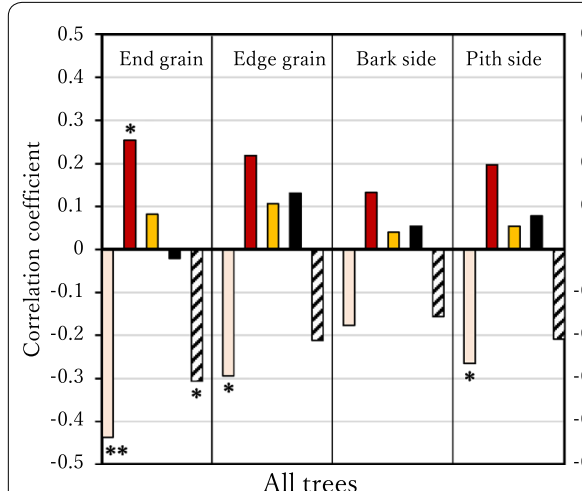

All trees

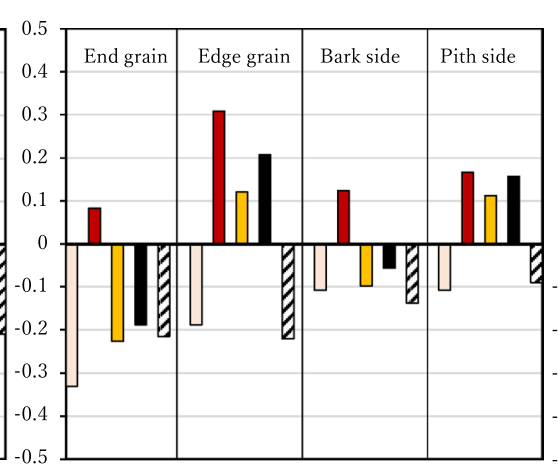

Conifers

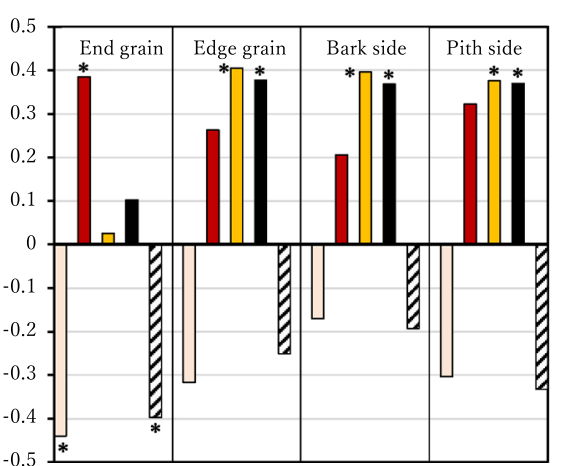

Broadleaf trees

\section{$\square L^{*} \quad \square a^{*} \quad \square b^{*} \quad \square C^{*} \quad \square h$}

Fig. 7 Correlations between density and $L^{*}, a^{*}, b^{*}, C^{*}, h$ of each measured plane. Significance level ${ }^{*} p<0.05,{ }^{* *} p<0.01$ 

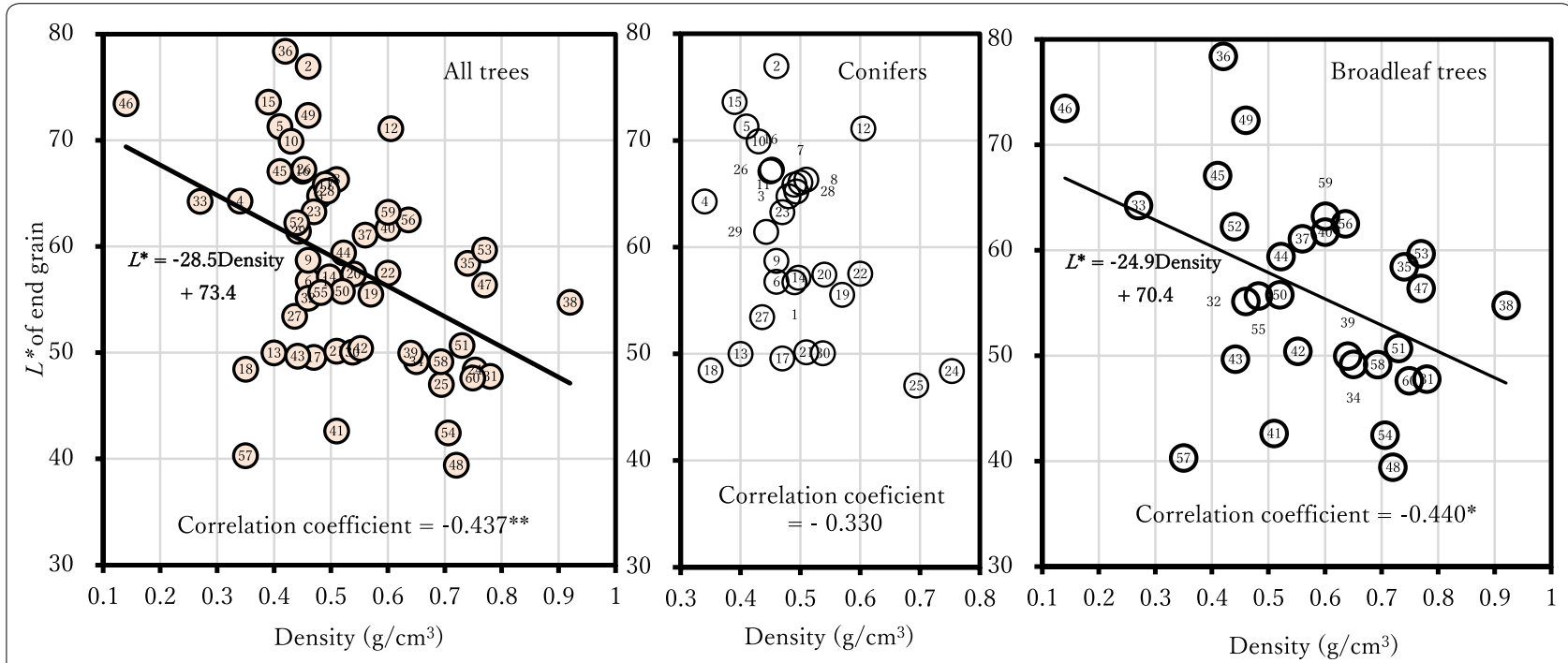

Fig. 8 Correlation diagrams between density and $L^{*}$ of end grain of each test piece. Each test piece number is shown as in Tables 1 and 3
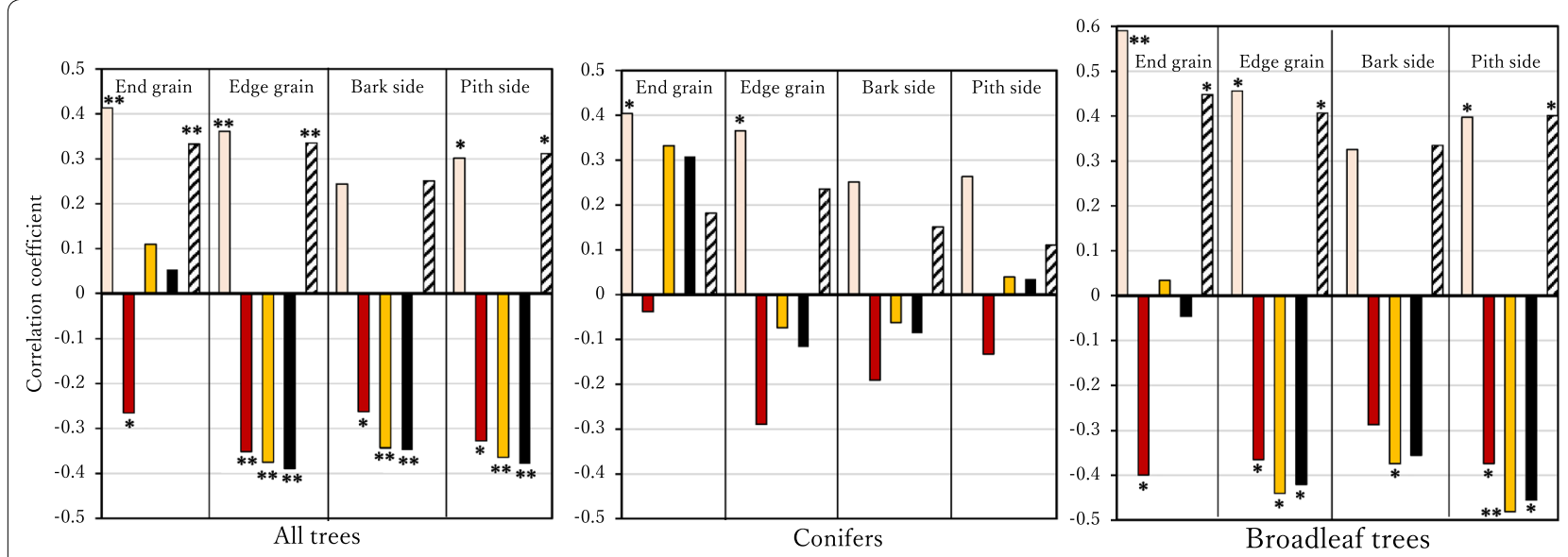

$\square L^{*} \quad \square a^{*} \quad \square b^{*} \quad \square C^{*} \quad \square h$

Fig. 9 Correlations between AARW and $L^{*}, a^{*}, b^{*}, C^{*}, h$ of each measured plane. Significance level ${ }^{*} p<0.05,{ }^{* *} p<0.01$ 


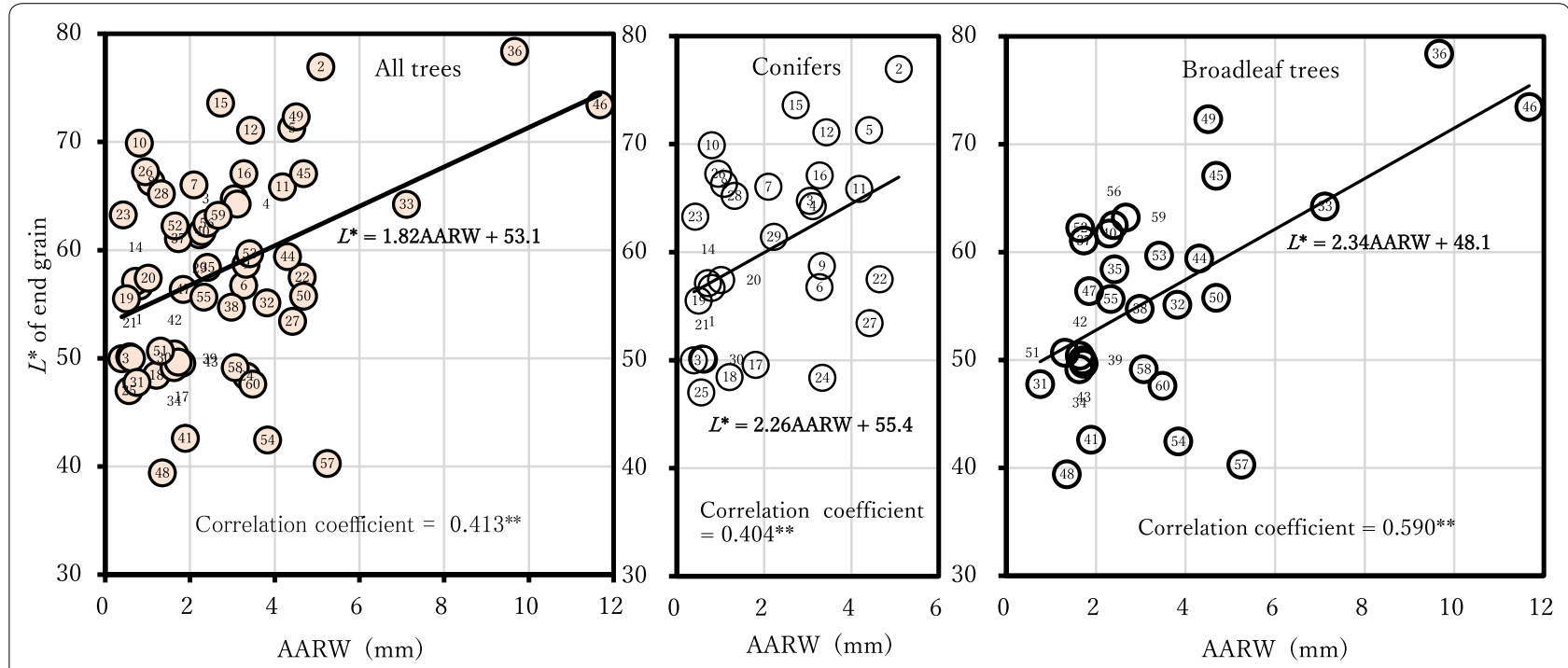

Fig. 10 Correlation diagrams between AARW and $L^{*}$ of end grain of each test piece. Each test piece number is shown as in Tables 1 and 3. Significance test results of correlation coefficient ${ }^{* *} p<0.01$

\section{Abbreviation}

AARW: Average of annual ring width.

\section{Acknowledgements}

Not applicable.

Part of this article was presented at the 67th Annual Meeting of Japan Wood Research Society in Fukuoka, March 2017.

\section{Authors' contributions}

$\mathrm{SHi}$ and $\mathrm{SHa}$ designed this study and prepared test pieces. Both measured the glossiness and color of the test pieces and analyzed the measurement results. $\mathrm{MO}$ considered the analysis results. SHi then wrote the manuscript. All authors read and approved the final manuscript.

\section{Funding}

No specific grant was received.

\section{Availability of data and materials}

The datasets used and analyzed during the current study are available from the corresponding author on reasonable request.

\section{Ethics approval and consent to participate}

Not applicable.

\section{Consent for publication}

Not applicable.

\section{Competing interests}

The authors declare that they have no competing interests.

\section{Author details}

${ }^{1}$ Okayama University Graduate School of Education, Tsushimanaka, Kita-Ku, Okayama 700-8530, Japan. ${ }^{2}$ People Software Corporation, Achi, Kurashiki, Okayama 710-0055, Japan. ${ }^{3}$ Former Graduate School of Agricultural and Life Sciences, The University of Tokyo, Yayoi, Bunkyo-Ku, Tokyo 113-8657, Japan.

Received: 9 January 2020 Accepted: 1 May 2020

Published online: 18 May 2020

\section{References}

1. Nitta S (1951) Colorimetry on woods by the trichromatic colorimeter. J Jap Forest Soc. https://doi.org/10.11519/jjfs1934.33.376 (In Japanese)

2. Sadoh T (1985) Light and wood. In: Fushitani M, ed. Physics of wood, Buneido, Tokyo, pp 234-238 (In Japanese)

3. Kitamura Y (1987) Measured colour values of important domestic and imported wood. Bull For Prod Res Inst 347:203-239 (In Japanese)

4. Vetter R, Coradin V, Martino E, Camargos J (1990) Wood colour-a comparison between determination methods. IAWA Bull 11(4):429-439. https ://doi.org/10.1163/22941932-90000534

5. Brunner C, Shaw G, Butler D, Funck J (1990) Using color in machine vision systems for wood processing. Wood Fiber Sci 22(4):413-428

6. Masuda M (1993) Visual characteristics. Wood Ind 48(11):536-542 (In Japanese)

7. Klumpers J, Janin G, Becker M, Lévy G (1993) The influences of age, extractive content and soil water on wood color in oak: the possible genetic determination of wood color. Ann Sci For 50:403-409. https://doi. org/10.1051/forest:19930746

8. Masuda M (1995) Wood color range and characteristics. In: Okano T (ed) Wood living environment handbook. Asakura Publishing, Tokyo, p 129

9. Masuda M (1995) Color. In: Takahashi T, Suzuki S, Nakao T (eds) Wood science course 5 environment. Kaiseisha Press, Shiga, p 57

10. Katuščák S, Kucera L, Varga S, Vrska M, Ceppan M, Suty S, Jablonsky M (2002) New method of recognition of wood species: increasing of the effectiveness of colorimetric recognition of Picea excelsa and Abies alba. Drevarsky Vyskum/Wood Res 47(1):1-12

11. Faria J, Martins T, Ferreira M, Santos C (2008) A Computer vision system for color grading wood boards using fuzzy logic. IEEE Int Symp Industr Electr. https://doi.org/10.1109/ISIE.2008.4677036

12. Defoirdt N, Wuijtens I, Boever L, Coppens H, Bulcke J, Acke J (2012) A colour assessment methodology for oak wood. Ann Forest Sci 69:939-946. https://doi.org/10.1007/s13595-012-0214-3

13. Moya R, Alvarado J (2012) Variation of wood color parameters of Tectona grandis and its relationship with physical environmental factors. Ann Forest Sci 69:947-959. https://doi.org/10.1007/s13595-012-0217-0

14. Moya R, Fallas R, Bonilla P, Tenorio C (2012) Relationship between wood color parameters measured by the CIE lab system and extractive and phenol content in Acacia mangium and Vochysia guatemalensis from fastgrowth plantations. Molecules 17:3639-3652. https://doi.org/10.3390/ molecules 17043639 
15. Ueda M, Nakamura M, Kitamori A, Komatsu K (2013) Minute color measurement of sugi timber (Cryptomeria japonica) dried by five conditions I. Mokuzai Gakkaishi 59(6):339-345. https://doi.org/10.2488/jwrs.59.339 (In Japanese)

16. Nakamura M, Ueda M (2013) Minute color measurement of sugi timber (Cryptomeria japonica) Dried by five conditions II. Mokuzai Gakkaishi 59(6):346-352. https://doi.org/10.2488/jwrs.59.346 (In Japanese)

17. Tanaka M (ed) (2009) JIS Z 2101, Methods of test for wood, Japanese Standards Association, Tokyo, pp 35-36 (In Japanese)

18. Takahashi T (1982) Hardness. In: JSMS Committee on Wood and WoodBased Materials (ed) Wood Engineering Dictionary, INDUSTRIAL PUBLISHING, Tokyo, pp 85-86 (In Japanese)

19. Yuuhi T (ed) (2013) JIS Z 8781-4, Colorimetry-Part4: CIE $1976 L^{*} a^{*} b^{*}$ colour space. Japanese Standards Association, Tokyo (In Japanese)

20. International organization for standardization (2019) ISO/CIE 11664-4, Colorimetry-Part 4: CIE 1976 L*a*b* colour space. ISO copyright office, Geneva

21. KONICA MINOLTA, INC. (2019) Color systems used for digitizing colors 1. In: A wisdom bag that you can enjoy. https://www.konicaminolta.jp/instr uments/knowledge/color/section2/02.html. Accessed 17 Nov 2019 (In Japanese)
22. Masuda M (1995) Gloss anisotropy: Difference in gloss depending on how light strikes. In: Okano T (ed) Wood Living Environment Handbook. Asakura Publishing, Tokyo, pp 133-134 (In Japanese)

23. Hirata S, Toyoda H, Ohta M (2017) Reducing eye fatigue through the use of wood. J Wood Sci 63:401-408. https://doi.org/10.1007/s1008 6-017-1629-0

24. Sugimoto H, Rikitake T, Sugimori M (2018) Optical reflection and transmission of sugi wood in visible light. Mokuzai Gakkaishi 64(2):66-71. https://doi.org/10.2488/jwrs.64.66 (In Japanese)

25. Sugimoto H, Kawabuchi S, Sugimori M, Gril J (2018) Reflection and transmission of visible light by sugi wood: effects of cellular structure and densification. J Wood Sci 64:738-744. https://doi.org/10.1007/s1008 6-018-1751-7

26. Ohshima K, Sugimoto, H, Sugimori M (2019) Effect of fiber inclination on total transmission and total reflection. In: Proceedings of the 69th annual meeting of JWRS. C15-P-10 (In Japanese)

\section{Publisher's Note}

Springer Nature remains neutral with regard to jurisdictional claims in published maps and institutional affiliations.

\section{Submit your manuscript to a SpringerOpen ${ }^{\odot}$ journal and benefit from:}

- Convenient online submission

- Rigorous peer review

- Open access: articles freely available online

- High visibility within the field

- Retaining the copyright to your article

Submit your next manuscript at $\boldsymbol{\nabla}$ springeropen.com 